\title{
STRATEGI SEKOLAH DALAM PRAKTIK PEMBELAJARAN JARAK JAUH PADA SITUASI PANDEMI COVID 19
}

\author{
HAROMAIN \\ Administrasi Pendidikan, FIPP Undikma \\ Email : haromain@undikma.ac.id
}

\begin{abstract}
ABSTRAK
Artikel ini merupakan hasil penelitian yang menggambarkan tentang pelaksanaan pembelajaran jarak jauh yang difokuskan pada aspek perencanaan, pengorganisasian, implementasi serta pengawasan pembelajaran jarak jauh. Penelitian menggunakan pendekatan kualitatif dengan rancangan studi kasus pada SMP Negeri 1 Pringgarata. Hasil penelitian menunjukkan bahwa perencanaan pembelajaran jarak jauh dilakukan melalui rapat umum dan sosialisasi. Pengorganisasian dilakukan dengan menjalin kerjasama diantara komponen sekolah, menyusun jadwal serta membentuk kelompok dan lokasi belajar. Pelaksanaan pembelajaran jarak jauh menggunakan media sosial dan platform e-learning sekolah. Sedangkan pengawasan dilakukan untuk memastikan proses pembelajaran berlangsung sesuai rencana.
\end{abstract}

Kata kunci: manajemen sekolah, pembelajaran jarak jauh, pandemi covid 19

\section{PENDAHULUAN}

Penyebaran Covid-19 yang dengan cepat meluas ke seluruh dunia, menimbulkan perubahan pola aktivitas pada seluruh sektor kehidupan manusia pada saat ini. Hal serupa juga terjadi di Negara kita, yakni Indonesia. Menyikapi cepatnya penyebaran virus tersebut, pemerintah dengan sigap mengambil kebijakan dengan mengeluarkan Peraturan Pemerintah RI No 21 Tahun 2020 tentang Pembatasan Sosial Berskala Besar dalam Rangka Percepatan Penanganan Covid-19 tidak terkecuali di bidang pendidikan. Melalui Kementerian Pendidikan dan Kebudayaan (Kemendikbud) Indonesia memberlakukan kebijakan jarak jauh melalui metode sekolah online, melalui surat edaran No 15 Tahun 2020 Tentang Pedoman Penyelenggaraan Belajar dari Rumah dalam Masa Darurat Penyebaran Covid-19. Sekolah online ini diberlakukan bagi setiap kalangan pelajar dan mahasiswa di seluruh wilayah Indonesia. Di mana pembelajaran atau perkuliahan secara langsung melalui tatap muka diganti dengan pola pembelajaran daring atau online. Sekolah online ini bertujuan untuk memutus mata rantai penyebaran Covid-19.

Adanya pandemi Covid-19 membuat semua sarana mati atau ditutup sementara, termasuk kegiatan belajar mengajar, pemerintah Provinsi Nusa Tenggara meningkatkan status kondisi siaga darurat menjadi tanggap darurat dengan di tandatanganinya keputusan Gubernur Nomor 360-450 Tahun 2020 tentang Status Tanggap Darurat Bencana Non Alam Covid-19 di Provinsi Nusa Tenggara Barat, yang mulai berlaku sejak 15 April s.d 28 April 2020, dan akan diperpanjang sesuai dengan kondisi dan perkembangan yang ada.. Berkaitan dengan hal tersebut, sesuai dengan penelitian dari Khasanah (2020) pada awalnya banyak orang tua yang menolak pembelajaran daring untuk anaknya, karena menggunakan teknologi. Namun seiring waktu, orang tua mulai menerima pembelajaran daring ini (Ihsanuddin, 2020).

Pada dasarnya setiap anak memiliki potensi yang tidak terbatas. Tetapi ada beberapa faktor yang dapat mempengaruhi apakah mereka pada akhirnya memenuhi potensi tersebut. Disinilah peran humas dalam hal pelibatan orang tua terurama ibu, saat ini menjadi bertambah berat setelah pemerintah memutuskan penerapan kebijakan proses belajar mengajar yang diubah menjadi online artinya belajar mengajar selama pandemi Covid-19. Memang dari berbagai Dinas Pendidikan dan Kebudayaan Jakarta, terdapat panduan normatif seperti dalam akun Instagram tentang tugas untuk kepala sekolah, guru, orang tua dan siswa. Misalnya tugas Kepala Sekolah adalah memberikan surat tugas kepada guru serta surat edaran kepada orang tua untuk melakukan kegiatan pembelajaran di rumah, dalam rangka meningkatkan kewaspadaan dan pencegahan penularan Covid-19 di sekolah. 
Di era globalisasi, setiap lembaga pendidikan dituntut untuk bisa memadukan antara kepentingan sosial dengan pendekatan promosi dan pemasaran. Memadukan dua kepentingan tersebut merupakan karakteristik tersendiri bagi lembaga pendidikan. Lembaga pendidikan yang merupakan suatu sistem yang terbuka pasti akan mengadakan hubungan dengan masyarakat sekelilingnya. Sebagaimana Sondang Siagian (Siagian, 1974) mengungkapkan bahwa manajemen adalah kemampuan dan keterampilan untuk mengatur agar memperoleh suatu hasil dalam rangka mencapai tujuan melalui kegiatan orang lain, terlihat dengan jelas manajemen mempunyai peran yang cukup besar bagi perkembangan lembaga di masa yang akan datang.

Menurut E. Mulyasa model manajemen humas merupakan seluruh proses-proses kegiatan yang direncanakan dan diusahakan secara sengaja dan bersungguh-sungguh, disertai pembinaan secara kontinyu untuk mendapatkan simpati dari masyarakat pada umumnya, dan khusunya masyarakat yang berkepentingan langsung dengan sekolah terutama orang tua. Simpati masyarakat akan tumbuh melalui upaya-upaya sekolah dalam menjalin hubungan secara intensif dan proaktif di samping membangun citra lembaga yang baik (Mulyasa, 2013)

Bagi guru yang juga memiliki tugas di sekolah, seperti menyiapkan bahan ajar yang akan diunggah kepada siswa, menentukan media belajar seperti grup Whatsapp, Email, Google Classroom, atau aplikasi media belajar lain sesuai rekomendasi Kemendikbud. Kepada para orang tua juga diminta untuk memastikan siswa melaksanakan kegiatan belajar di rumah masing-masing, membatasi izin kegiatan di luar rumah, berkordinasi dengan wali kelas, guru atau sekolah, membantu siswa menerapkan Pola Hidup Bersih Sehat (PHBS) di rumah dan sebagainya dan juga kepada para siswa diminta agar memperlajari bahan atau materi yang telah diunggah guru melalui media yang telah disepakati. Kemudian melakukan diskusi dengan guru melalui media online jika masih ada hal yang kurang jelas dari materi yang diberikan.

Strategi manajemen Humas terutama dalam halnya peran orang tua dalam situasi pandemi Covid-19 ini memiliki kedudukan yang fundamental. Begitupula dengan kondisi yang ada di SMPN 1 saat ini. SMPN 1 Pringgarata merupakan sekolah menengah pertama yang cukup favorit dengan berbagai kegiatan serta ekstrakurikuler yang beragam. Sekolah tersebut terletak di desa Pringgarata yang lokasinya cukup strategis dan mudah diakses oleh setiap masyarakat. Peneliti sebelumnya pernah melakukan observasi untuk mengetahui bagaimana situasi dan kondisi yang ada di sekolah SMPN 1 Pringgarata tersebut. Dari observasi yang pernah dilakukan, peneliti dapat melihat bagaimana keaktifan dari guru-guru nya pada masa pandemi saat ini.

Di masa pandemi Covid-19 saat ini, strategi manajemen humas dalam kegiatan pembelajaran jarak jauh tentunya perlu dukungan dari orang tua siswa. Karena melihat kondisi yang tidak memungkinkan bagi siswa untuk belajar tatap muka di sekolah. Dari sanalah peran orang tua sebagai guru bagi anak-anaknya, dimana orang tua dapat membimbing anaknya dalam belajar secara jarak jauh. Di samping itu, pembelajaran yang dilakukan secara jarak jauh dapat memudahkan orang tua dalam mengontrol perkembangan anaknya selama belajar, serta orang tua dapat mengetahui seberapa jauh kemampuan anaknya dalam menguasai pembelajaran yang diberikan.

Selain dari peran orang tua, siswa juga lebih aktif dalam melakukan pembelajaran jarak jauh. Dari pembelajaran jarak jauh yang dilakukan, orang tua juga memberikan fasilitas pada anaknya agar dapat menunjang kelancaran dalam proses pembelajaran. Serta memberikan perhatian lebih kepada anaknya agar tidak merasa jenuh ketika belajar secara jarak jauh atau online.

Namun perlu disadari kesiapan dari guru, siswa dan orang tua terhadap pembelajaran jarak jauh masih menjadi permasalahan karena perpindahan sistem belajar konvensional kesistem pembelajaran online amat sangat mendadak tanpa ada persiapan yang matang. Tetapi semua ini harus tetap dilaksanakan agar proses pembelajaran di SMPN 1 Pringgarata dapat berjalan lancar dan siswa tetap aktif mengikuti pembelajaran walaupun dalam kondisi pandemi. 


\section{METODE PENELITIAN}

Penelitian ini menggunakan pendekatan kualitatif dengan rancangan studi kasus. Lokasi penelitian dilaksanakan di SMP Negeri 1 Pringgarata. Sumber data dalam penelitian ini adalah kepala sekolah, wakil kepala sekolah, guru, serta orang tua siswa. Analisis data dilakukan selama proses penelitian berlangsung dengan menggunakan alur pengumpulan data, reduksi data, penyajian data serta penarikan kesimpulan.

\section{HASIL DAN PEMBAHASAN}

\section{Hasil}

\section{Perencanaan Pembelajaran Jarak Jauh}

Perencanaan pembelajaran jarak jauh di SMPN 1 Pringgarata yang akan dilaksanakan selama pandemi Covid-19 dengan beberapa tahapan perencanaan sebagai berikut, yaitu:

a. dalam menyikapi pandemi covid 19, sekolah tersebut yakni dengan melakukan rapat secara umum dengan seluruh dewan guru dan tenaga kependidikan yang ada di lingkungan SMPN 1 Pringgarata dalam rangka merumuskan pembelajaran yang akan dilakukan secara jarak jauh. Adanya rapat umum yang dilakukan pihak sekolah mengharuskan Waka Humas melakukan sosialisasi kepada para pemangku kepentingan maupun pihak terkait di lingkungan satuan pendidikan terutama orang tua siswa, dengan tujuan memberikan informasi awal terkait pembelajaran yang akan dilakukan secara jarak jauh di masa pandemi Covid-19.

b. perencanaan yang dirumuskan pihak sekolah dalam pembelajaran jarak jauh dengan menentukan metode yang akan digunakan dalam proses KBM selama pandemi Covid-19. Metode yang disepakati yakni dengan membuat titik-titik atau lokasi pembelajaran yang akan dilaksanakan baik dirumah guru atau siswa itu sendiri (luring).

c. dalam upaya meminimalisir penyebaran Covid-19 pihak sekolah juga merencanakan pembelajaran yang akan dilakukan secara daring dengan memanfaatkan teknologi yang ada dan mudah diakses oleh guru maupun siswa seperti aplikasi Whatsapp.

\section{Pengorganisasian Pembelajaran Jarak Jauh}

Pengorganisasian yang dilakukan di SMPN 1 Pringgarata menjadi satu hal yang sangat penting dalam upaya memperlancar pelaksanaan pembelajaran jarak jauh yang tentunya mengacu pada perencanaan yang telah disepakati sebelumnya seperti:

a. Melakukan kerjasama atau koordinasi antar Waka Humas, Waka Kurikulum, dan Waka Kesiswaan dalam usaha untuk memaksimalkan proses pembelajaran.

b. Pembelajaran jarak jauh yang akan dilaksanakan baik itu secara daring maupun luring terlebih dahulu dengan dibuatkannya jadwal KBM agar memudahkan guru atau siswa dalam pelaksanaannya.

c. Adanya pandemi Covid-19 ini yang mengakibatkan pihak sekolah hanya melakukan proses KBM saja karena tidak memungkinkan untuk sekolah melakukan kegiatan Ekstrakurikuler atau kebiasaan-kebiasaan sebelum pandemi.

d. KBM yang akan dilaksanakan di sekolah dengan tetap mengacu pada Surat Edaran dari Pemerintah.

\section{Implementasi Pembelajaran Jarak Jauh}

Pelaksanaan pembelajaran jarak jauh yang dilakukan di SMPN 1 Pringgarata di masa pandemi ini dilaksanakan oleh pihak sekolah dengan maksimal. Akan tetapi dalam praktiknya masih terdapat beberapa kendala, diantaranya:

a. Pelaksanaan pembelajaran yang dilakukan secara daring oleh pihak sekolah untuk meminimalisir penyebaran Covid-19 melalui aplikasi Whatsapp. Namun pembelajaran yang dilakukan melalui daring tersebut masih mengalami kendala dari siswa yang tidak merata dalam memiliki gadget, adapun yang memiliki gadget namun terkendala oleh sinyal 
untuk siswa yang berada di daerah terpencil. Oleh sebab itulah pembelajaran daring tersebut masih belum maksimal dilakukan.

b. Sedangkan dalam pelaksanaan pembelajaran secara luring yang dilaksanakan baik itu dirumah guru maupun siswa dengan tetap mengikuti titik-titik yang sudah dibuat. Namun kendalanya yaitu dari pembagian siswa yang belajar masih banyak yang jarang masuk atau malas mengikuti KBM tersebut karena di masa pandemi ini siswa cenderung malas.

\section{Pengawasan Pembelajaran Jarak Jauh}

Pengawasan pembelajaran yang dilakukan oleh pihak sekolah dalam upaya menjamin keberlangsungan proses pembelajaran jarak jauh berjalan dengan maksimal sesuai perencanaan.

a. Pengawasan pembelajaran jarak jauh bertujuan untuk mengetahui kondisi di lapangan terhadap pelaksanaan pembelajaran yang sedang di terapkan.

b. Mengetahui masih banyaknya kendala yang di hadapi oleh guru maupun siswa selama pembelajaran berlangsung.

c. Pengawasan yang ketat terhadap protokol kesehatan yang harus diterapkan baik oleh siswa maupun guru-gurunya.

\section{Pembahasan}

Pada dasarnya perencanaan (planning) adalah menentukan kegiatan yang hendak dilakukan, agar hasil yang dicapai sesuai dengan harapan. Perencanaan merupakan fungsi awal dari seluruh fungsi manajemen, tanpa adanya perencanaan maka tidak dapat diketahui usaha yang dilakukan mencapai hasil atau tidak.

Strategi manajemen humas yang sebenarnya menjunjung tinggi kebenaran dan kejujuran. Segala program humas baik itu program yang berjangka panjang maupun yang berjangka pendek harus direncanakan dengan cermat dan hati-hati sedemikian rupa sehingga akan diperoleh hasil-hasil yang nyata.

Adapun perencanaan yang dilakukan di SMPN 1 Pringgarata yakni dengan melakukan rapat secara umum yang dihadiri oleh semua pendidik dan tenaga kependidikan yang di lingkungan sekolah. Rapat tersebut dilakukan di ruang sekolah dengan menggunakan ruang kelas sebagai tempat untuk melaksanakan rapat secara umum. Rapat tersebut dilaksanakan untuk merumuskan pembelajaran yang akan dilaksanakan di masa pandemi sesuai dengan Surat Edaran yang dikeluarkan oleh Pemerintah. Karena adanya pandemi yang mengharuskan semua sekolah terutama dalam hal ini SMPN 1 Pringgarata yang ikut terdampak dari adanya pandemi Covid-19 ini yang mengaharuskan pembelajaran dilakukan secara jarak jauh.

Dalam rapat tersebut dirumuskan beberapa perencanaan untuk melancarkan pelaksanaan pembelajaran yang akan dilakukan secara jarak jauh yaitu sebagai berikut:

a. Perencanaan yang dilakukan oleh pihak sekolah tujuannya untuk merumuskan apa saja yang akan menjadi penunjang dalam pelaksanaan pembelajaran jarak jauh tersebut. Tentu saja dalam hal ini pihak sekolah menentuka metode apa yang dapat digunakan untuk mempermudah pembelajaran yang akan dilaksanakan. Penentuan metode disini yaitu dengan tetap melihat situasi dan kondisi dari siswa itu sendiri, oleh karena itu pihak sekolah merumuskan dua metode pembelajaran yang akan dilakukan seperti pembelajaran yang akan dilakukan secara daring dengan memanfaatkan teknologi yang ada untuk dapat digunakan dalam proses pembelajarannya. Kemudian menggunakan metode pembelajaran secara luring yaitu dengan melakukan proses pembelajaran sesuai dengan kelompok belajar yang sudah ditentukan.

b. Perencanaan dalam pelaksanaan pembelajaran yang akan dilakukan secara jarak jauh dengan menggunakan teknologi disini yaitu dengan memanfaatkan media Whatsapp. Karena melihat dari kondisi siswa yang tidak merata dalam meiliki atau menggunakan gadget, dari sanalah pihak sekolah hanya dapat menggunakan aplikasi Wa Grup untuk menunjang kelancaran dalam proses pembelajaran jarak jauh tersebut. 
c. Perencanaan yang dirumuskan dengan menggunakan metode pembelajaran secara luring disini, pihak sekolah merencanakan agar pembelajaran dilakukan dirumah guru atau dirumah siswa langsung. Tentunya dengan membentuk kelompok-kelompok belajar dimasing-masing wilayah terdekat dari siswa tersebut.sehingga nanti dapat memudahkan siswa dan gurunya dalampelaksanaan KBM. Adapun untuk mengantisipasi siswa yang radiusnya jauh dari kelompok belajar yang sudah ditentukan. Pihak sekolah memberikan kebebasan kepada siswa untuk menentukan kelompok belajar mereka sendiri dengan teman-teman terdekatnya kemudian guru-gurunya dapat mengunjungi rumah siswa yang siap ditempati untuk melaksanakan KBM tersebut.

d. Dari rumusan perencanaan maka hal selanjutnya yang dilakukan oleh manajemen humas yaitu dengan melakukan sosialisasi kepada para pemangku kepentingan di lingkungan satuan pendidikan terkhusus pada orang tua siswa. Adapun sosialisai yang dilakukan dengan memberikan informasi terkait dengan tanggal mulai pembelajaran jarak jauh, metode apa yang akan digunakan untuk menunjang keberlangsungan KBM yanag akan dilaksanakan. Sosialisasi yang dilakukan yaitu dengan membuat Surat Edaran dari Sekolah dan informasi yang akan diberikan, pihak humas dapat mengirimkannya melalui via Whatsapp.

Pengorganisasian merupakan proses penyusunan struktur organisasi, sumber daya yang dimilikinya dan lingkungan yang melingkupinya. Pembagian kerja adalah pemerincian tugas agar setiap individu dalam organisasi bertanggungjawab untuk melaksnakans sekumpulan kegiatan yang terbatas. Kedua aspek ini merupakan dasar dari proses pengorganisasian suatu lembaga pendidikan untuk mencapai tujuan yang telah ditetapkan secara efisien dan efektif. (Hardjito. 2020)

Definisi dari pengorganisasian yang dilakukan oleh Waka Humas di SMPN 1 Pringgarata yaitu dengan melakukan sistem kerjasama antar wakasek-wakasek yang ada di sekolah untuk memudahkan dalam kelancaran pembelajaran jarak jauh yang akan dilaksanakan. Dari kerjasama yang dilakukan pihak terkait dengan bekerjasama dalam pembagian tugas masing-masing. Mulai dari pembuatan jadwal pembelajaran, pembuatan kelompok belajar dan dimana lokasi pembelajaran akan dilakukan dan lainnya, seperti:

a. Pembuatan jadwal yang dilakukan oleh Waka Kurikulum dengan membagi beberapa mata pelajaran yang akan digunakan dalam pelaksanaan pembelajaran baik secara daring maupun luring. Penjadwalan dimaksudkan agar mempermudah siswa maupun guru dalam melakukan proses pembelajaran agar tidak bentrok dengan mata pelajaran lainnya.

b. Menentukan kelompok belajar sesuai dengan radius terdekat dari siswa itu sendiri. Setiap kelas dalam pembelajaran yang dilakukan secara luring atau BDR itu dibagi menjadi 1 kelompok yang terdiri dari 10 orang agar selama pembelajaran dilakukan tidak menjadi kerumunan dengan tetap menegaskan atau memperhatikan protokol kesehatan.

c. Penempatan lokasi pembelajaran yang akan digunakan untuk keberlangsungan proses KBM nya yaitu dengan dimana lokasi yang sekiranya strategis untuk digunakan sehingga pembelajaran dapat dilaksanakan dan juga kesiapan dari siswa maupun gurunya yang rumahnya akan digunakan sebagai tempat pembelajaran secara BDR.

d. Kegiatan yang berjalan hanya KBM saja, dikarenakan tidak memungkinkan bagi sekolah untuk menjalankan kegiatan rutin di sekolah seperti Ekstrakurikuler maupun kebiasaankebiasaan yang dilakukan setiap hari di sekolah.

e. Pembelajaran yang akan dilaksanakan pun tetap mengacu pada Surat Edaran yang diberikan oleh Pemerintah. Karena mau tidak mau siap tidak siap, sekolah harus tetap dilaksanakan walaupun dalam kondisi apapun, sebab pembelajaran dapat berlangsung walau tanpa tatap muka secara langsung.

Pelaksanaan pembelajaran yang dilakukan di SMPN 1 Pringgarata yang dilakukan secara daring maupun luring. Akan tetapi dari pelaksanaan pembelajaran tersebut pihak sekolah mengalami beberapa kendala yang terjadi pada siswanya. Kendala dalam pelaksanaannya menharuskan pihak sekolah untuk terus berusaha melakukan kegiatan pembelajaran tersebut 
semaksimal mungkin walaupun pembelajaran yang dilaksanakan mengalami kendala. Adapun kendala-kendala tersebut diantarannya:

a. Pembelajaran yang dilaksanakan secara daring yang mengharuskan siswa belajar dari rumah dengan menggunakan aplikasi-aplikasi yang dapat menunjang keberlangsungan pembelajaran tersebut. Akan tetapi dalam pelaksanaannya pihak sekolah mengalami kendala dari siswanya yang tidak merata dalam memiliki gadged sehingga yang paling efektif digunakan dalam pembelajaran dari yaitu hanya aplikasi Wa grup.

b. Kendala lainnya dalam pelaksanaan pembelajaran secara daring ini yaitu dari sinyal yang kurang memadai yang terdapat pada siswa yang jarak rumahnya masih di tempat-tempat terpencil.

c. Kendala dalam pembelajaran luring/KBM yang dilakukan dari rumah ke rumah dengan menggunakan kelompok belajar yaitu dari 10 orang dalam 1 kelompok kadang masih banyak yang tidak hadir untuk mengikuti KBM tersebut. Karena di masa pandemi ini siswa cenderung malas dalammegikuti pembelajaran karena pembelajaran yang dilakukan masih kurang maksimal.

Strategi sekolah dalam pengawasan selama pembelajaran jarak jauh di SMPN 1 Pringgarata yakni dengan mengikut sertakan orang tua siswa dalam pengawasan pembelajaran selama di rumah agar siswa tidak melakukan pekerjaan lain selain mengikuti pembelajaran selama pembelajaran berlangsung. Pengawasan yang dilakukan pihak sekolah dalam pembelajaran yang dilakukan dalam pembentukan kelompok belajar juga terdapat beberapa pengawasan diantaranya, yaitu:

a. Kepala Sekolah dengan dibantu oleh wakasek-wakasek yang memiliki tugas dalam melakukan pengawasan terhadap keterlaksanaan pembelajaran secara jarak jauh dengan langsung turun ke lapangan untuk memantau kondisi yang terjadi di lapangan sehingga dengan mudah pihak sekolah dapat mengetahui apa saja kendala maupun kekurangan selama pelaksanaan pembelajaean jarak jauh dilaksanakan. Sehingga peran manajemen humas nnati dapat memperbaiki atau menanggulangi kekurangan dalam pelaksanaan pembelajaran secara jarak jauh yang dilaksnaakan di SMPN 1 Pringgarata.

b. Pembelajaran yang dilakukan di tempat atau titik yang sudah ditentukan oleh pihak sekolah dengan mengadakan perkumpumpulan baik oleh siswa maupun guru disana dengan tetap dihimbau untuk menjaga ketertiban terkait dengan protokol kesehatan yang harus tetap di taati.

\section{KESIMPULAN}

Berdasarkan hasil penelitian yang telah dilakukan mka penulis dapat mengambil kesimpulan bahwa strategi manajemen humas dalam pelaksanaan pembelajaran jarak jauh di masa pandemi Covid-19 di SMPN 1 Pringgarata dilakukan dengan menentukan perencanaan, pengorganisasian, pelaksanaan serta pengawasan dalam menunjang keberlangsungan pembelajaran jarak jauh.

Strategi sekolah dalam perencanaan pembelajaran jarak jauh di masa pandemi Covid-19 terdiri dari beberapa perencanaan diantaranya yaitu: melakukan rapat secara umum sesuai dengan surat edaran yang dikeluarkan pemerintah sehingga mengharuskan pihak sekolah melakukan pembelajaran secara jarak jauh, kemudian menentukan metode pembelajaran yang akan digunakan baik itu secara daring maupun luring dan kemudian akan dilaukannya sosialisasi terkait dengan pembelajaran jarak jauh yang akan dilaksanakan.

Pengorganisasian pembelajaran jarak jauh di masa pandemi Covid-19 di SMPN 1 Pringgarata yang terdiri dari: melakukan kerjasaman antar wakasek-wakasek serta guru mata pelajaran dan juga guru wali kelas agar memudahkan dalam pelaksanaan pembelajaran yang akan dilakukan secara jarak jauh baik itu dalam membuat jadwal pembelajaran, pembuatan kelompok belajar dan lokasi yang akan digunakan dalam kelancaran KBM nya.

Dalam pelaksanaan pembelajaran jarak jauh di masa pandemi Covid-19 di SMPN 1 Pringgarata yaitu terdapat beberapa kendala dalam pelaksanaannya yaitu: KBM yang 
dilaksanakan secara daring dengan menggunakan media Whatsapp namun tidak semua siswa memiliki gadged, kemudian terkendala oleh sinyal dan juga dalam pembelajaran daring yang dilakukan terkendala oleh siswa yang kadang banyak yang jarang masuk.

Sedangkan pengawasan pembelajaran jarak jauh di masa pandemi Covid-19 di SMPN 1 Pringgarata terdapat beberapa bentuk perbaikan dalam pengawasan yang dilakukan yaitu: dengan melakukan pengawasan secara langsung ke lokasi KBM, dengan menghimbau kepada orang tua wali agar tetap mengawasi ataumengontrol anaknya selama pembelajaran daring, dan juga dengan tetap mempertegas himbauan tentang protokol kesehatan terkait dengan $3 \mathrm{M}$.

\section{DAFTAR PUSTAKA}

Ihsanuddin. 2020. Fakta Lengkap Kasus Pertama Virus Corona di Indonesia. Kompas.com. diakses pada tanggal 30 Nopember 2020 pukul 22.00 Wita.

Kemendikbud. (2020). Panduan Penyelenggaraan Pembelajaran Pada Tahun Ajaran 2020/2021 dan Tahun Akademik di Masa Pandemi Coronavirus Diesease (Covid-19). Direktorat Jenderal Pendidikan Anak Usia Dini Non Formal Informal.

Khasanah, dkk. (2020). Pendidikan Dalam Masa Pandemi Covid-19. Jurnal Sinestesia Volume 10 No. 1 Tahun 2020

Mulyasa. (2007). Kurikulum Tingkat Satuan Pendidikan. Bandung: PT. Remaja Rosdakarya.

Mulyasa, E. (2013). Menjadi Kepala Madrasah dalam Konteks Menyukseskan MBS dan KBK. Bandung: PT. Remaja Rosdakarya

Ruslan, Rusady. (2014). Manajemen Publik Relation dan Media Komunikasi: Konsep dan Aplikasi. Jakarta: PT Raja Grafindo Persada.

Siagian. (1974). Administrasi Pembangunan. Jakarta: Gunung Agung. 